\title{
Utilizing natural resources of geothermal for villagers welfare
}

\author{
Sjahriati Rochmah ${ }^{1, *}$ and Tri Hayati ${ }^{1}$ \\ ${ }^{1}$ Faculty of Law, Universitas Indonesia, Indonesia
}

\begin{abstract}
In National Energy Policy, Indonesia is determined to reduce the use of artifact energy, and continue to promote and increase the use of new renewable energy that is used by 23 percent for electricity and transportation in 2025. Bio-energy contributed to 10 percent, Geothermal contributed to 7 percent, Hydro contributed to 3 percent and other new renewable energy contributed to 3 percent. During this time, portfolio/energy mix target had not reached, as in 2015, only reach 5\% and in 2016 reach 7 percent. To achieve the national energy resilience, government put geothermal as one of the supplies of pillar energy in the (National Medium-term Development Plan) RPJMN document. Beside government had promoted renewable energy as one of national strategy for instance to determine the energy policy and regulations for sustainable development but the result was not satisfied enough. The current article would explore the renewable energy governance in Indonesia that focused on the geothermal energy. The implementation of various policies, regulations, and programs should increase the awareness of the importance of renewable energy role in the sustainable development system. The transparency of fair governance and the participation of the stakeholders of development therefore it was a must.
\end{abstract}

\section{Introduction}

RPJMN 2015-2019 and Laws No 6 of 2014 put village as the important actor in national development party. The laws of village also emphasize the importance of empowerment, development, independency of villagers particularly related to the social development stated in article 4, such as: conservation and developing the custom, tradition, and culture of villagers; encouraging the initiative, movement, and participation of villagers to develop the village potential and assets for the sake of together welfare; establishing the government of village that professional, efficient and effective, inclusive, as well as responsible; improving the public service for villagers to accelerate the realization of public welfare; improving the socio-cultural resilience of villagers in order to establish the villagers that capable in maintaining the social unity as the part of national resilience; developing the villagers economy as well as settling the national development discrepancy; and strengthening the villagers as the development subject.

In accordance with the Regulation of Domestic Ministry Number 56 of 2015 about the Code and Data of Government Administration Area stated that the number of village in Indonesia is 74.754 villages. The direction village development is pointed to accelerate the realization of

\footnotetext{
${ }^{*}$ Corresponding author: sjahriati.rochmah711@gmail.com
} 
village independency consisting of acceleration of meeting public service and basic service needs, administration of government, improvement of community independency and welfare, development of economy in village based on local wisdom. Moreover, the target of village development is reducing the number of underdeveloped village until 5.000 villages and increasing the number of independent village at least 2.000 villages. The direction from the President of Republic of Indonesia is reducing the number of underdeveloped village particularly 1.138 underdeveloped villages in the border area.

The implementation of Laws Number 6 of 2014 concerning Villages become the ways for revitalization and reconstruction of customary culture and the unity of customary law community to grow again and developed based on the initiative of community in the scope of authority based on the origin rights and local authority in village scale, in line with the RPJMN document of 2015-2019 and Nawacita (Nine agenda) of the President of Republic of Indonesia which put village as the arena and development subject that turn on the village independency in the field of economy, ecology, social and culture. It is in line with the Sustainable Development Goals point 7 (affordable and clean energy) to ensure access to affordable, reliable, sustainable and modern energy for all which will achieved by 2030. Sustainable development goals (SDGs) is an aspiration for the realization of long-term sustainable development. SDGs covers the universal scale, with a comprehensive framework to assist the countries in the world to achieve sustainable development, through three approaches, i.e. economic development, openness in the social order, and environmental sustainability [1].

The Ministry of Village, Underdeveloped Regions Development and Transmigration through the Regulation of The Ministry of Village, Underdeveloped Regions Development and Transmigration Number 1 of 2015 concerning the Guidelines of Authority Based on the Origin Rights and Local Authority in village scale try to ensure the development quality in the context of administration of village government and villagers empowerment including the unity of customary law community, art, and culture in the case of meeting the basic social service needs in village beside also ensure the village and customary law community become the development subject on the initiatives, development movement in the field of education, health, social, economy and culture as well as the management of local potential based on the local wisdom in the frame of the Unity of State of Republic of Indonesia. Recognition, reverence, protection, and development of the rights of customary community can be the strategy in empowering the custom, local wisdom and culture of villagers. Escorting the implementation of Laws No 6 of 2014 consistently and sustainably through facilitation, supervision and accompaniment as well as ensuring the implementation regulation device are in line with the substance, soul, and spirit of Village Laws should be the guideline in determining regulations. Socio-cultural resilience is one of the three important elements of independent village beside the economical resilience and ecological resilience.

However, developing village is not as easy as flipping hand. There are many obstacles occurred, from the paradigmatic substantial problems, overlapping regulations, until the technical terms. The competition of ideas had developed since the discussion of RUU concerning Village between the parties with orientation to the government (governmental approach) and the party with community base (community approach). UU Number 6 of 2014 concerning Village was the result of compromise. That ideas competition was triggered by long history of village and the experiences, perceptions, interests, also idealism of each party. The born of Laws Number 6 of 2014 remain have many works to do, thus the controversy stated in that Laws can be implemented clearly without violate the philosophical basis and paradigm used. The born of new ministry which settle Village, development of underdeveloped regions and transmigration is political sign that the government in Joko Widodo-Jusuf Kalla era will provide bigger contribution in village as a community, not as "apparent governmental unit" like in the previous periods. 


\section{Natural resources of geothermal}

The use of natural resources either in national level or local level still become the big challenge how the natural resources can be used as much as possible for the community welfare. Geothermal as renewable energy should be able to participate in the case of facing the energy crisis that continues to haunt. How to manage the geothermal energy resources utilization from the side of regulation at the center to the regions up to how big its impact for community welfare in village are required to be strived in order the purpose of a just, prosperous, and socially just nation and state can be achieved.

Geothermal management is regardless from the journey of regulation history before independency [2]. Until now, the geothermal management is considered as not maximally applied, as the alternative energy the substitution of artifact energy. Therefore, it is necessary to look back that journey of regulation history, aiming to see the management pattern that can be the example of development in the future [3]. In this globalization era, geothermal is expected its benefits particularly related to the reduction of greenhouse gas emissions. The administration of geothermal in Indonesia has ebb and flow of regulations and provisions. The tidal and different provisions of government reflect the variety of commitment and attention of government on the administration of geothermal in Indonesia, since the era before independency until the reformation era at present.

National energy policy including the renewable energy policy (geothermal) gives important role in achieving the energy sovereignty. To achieve that energy sovereignty, the presence of State and the role of government become important and so that Government should be creative and fair in determining the policies that support the national energy resilience. The national energy policy should take sides with the development of education, technology, and also the development of economy for community which in the end fulfills the aim of prospering the community.

Geothermal administration is undeveloped field in energy sector business in Indonesia and recently be developed more intensive in the beginning of millennium era to attract the investors' interest in Indonesia. However, the effort of attracting investor in order to develop the geothermal administration in Indonesia has not optimal regarding the ambiguity of investment regulations, for instance from the licensing up to the distribution and selling regulation. Moreover, there is unsynchronized and disharmony coordination between the Government at center and at region, even by the issuing of Laws Number 23 of 2014 concerning Regional Government, it more obscures the terms of authority of geothermal administration licensing, which certainly causes the climate of investment in Indonesia not conducive.

The functional division in Laws Number 23 of 2014 concerning Regional Government and the presence of origin authority and local authority with village scale in Laws number 6 of 2014 concerning Village more indicate the potential of disharmony or at least the existence of hegemony from government at center and government at province and government at regency on the village government. Scrambling interest on the value of geothermal utilization for community welfare is always becomes the jargon scrambled by stakeholders.

Geothermal administration during this time is based on the laws Number 21 of 2014 regulate the license of geothermal administration centered in Central Government, not in Provincial and Regency Government. By applying the Laws Number 23 of 2014 concerning the Regional Government, regional government apparatus has perception that licensing concerning geothermal energy is also changed. In the Laws of regional Government it is regulated that the indirect licensing of geothermal (project of geothermal energy utilization as the electrical power 
source) is the authority of central government, whereas for direct geothermal utilization (i.e. tourism destination, hot spring water pool) become the authority of Regional Government of Regency where the geothermal source exist. Along with the presence of Laws Number 6 of 2014 concerning Village, it become important question if the regulations existed are supporting each other or borrowing Asshiddiqie phrase, has disharmony [4].

\section{Method}

The current article use qualitative method to assess village authority after Law Number 6 of 2014, its process and its outcomes in utilizing geothermal energy for villagers welfare. Specifically, using comparative approach in regard to the Laws No 6 of 2014, Laws No 21 of 2014 and the Law No 23 of 2014. It is focusing on the function of the law in regard to the reality happened in society, at this point, the village. The approach will examine what could be the function of law comparison in its simple meaning, such as the goal of comparison and how that function can be realized and the objective can be achieved [5-6].

\section{Discussion}

Considering this article is related to the village authority in conducting the geothermal utilization then the focus of regulations discussion will refer to 3 laws, namely:

1) Laws Number 6 of 2014 concerning Village.

2) Laws Number 21 of 2014 concerning Geothermal.

3) Laws Number 23 of 2014 concerning Regional Government.

Table 1. Comparison between Laws Number 6 of 2014, Laws Number 21 of 2014, and Laws Number 23 of 2014.

\begin{tabular}{|c|l|l|l|l|}
\hline No & \multicolumn{1}{|c|}{ Issues } & Laws Number 6/2014 & \multicolumn{1}{c|}{$\begin{array}{c}\text { Laws Number } \\
\mathbf{2 1 / 2 0 1 4}\end{array}$} & $\begin{array}{c}\text { Laws Number } \\
\mathbf{2 3 / 2 0 1 4}\end{array}$ \\
\hline 1 & Authority & $\begin{array}{l}\text { Clearly gives authority } \\
\text { to the village to manage } \\
\text { geothermal for the } \\
\text { welfare. }\end{array}$ & $\begin{array}{l}\text { Not give authority } \\
\text { to the village to } \\
\text { manage and utilize } \\
\text { geothermal. }\end{array}$ & $\begin{array}{l}\text { Not give authority } \\
\text { to the village to } \\
\text { manage and utilize } \\
\text { geothermal. }\end{array}$ \\
\hline 2 & $\begin{array}{l}\text { Development } \\
\text { Typology }\end{array}$ & Participatory & Top Down & Top Down \\
\hline
\end{tabular}

The enactment of Law No. 6 of 2014 concerning Villages gives new hope to Indonesia. The village is expected to improve the country's economic wheels through village-scale natural resource management and environment sustainable. In contrast to Law No. 23 of 2014 concerning Regional Government, Village Law develops different perspectives and new concepts related to village and village governance. The Village Law provides recognition and respect for the village with its diversity, as well as provides clarity on the status and legal certainty of the village in the constitutional system of the Republic of Indonesia. This Village Law confirms about: implementation of village government; implementation of development; community development; and community empowerment based on Pancasila, the 1945 Constitution, the Unitary State of the Republic of Indonesia, and Bhinneka Tunggal Ika. One of the programs launched in Nawacita and the mandate of the RPJMN for the 2015-2019 period is to develop Indonesia from the suburb by strengthening regions to reach the government and communities in the village. 
In the provisions of the Village Law, village has the following authority: authority based on the rights of origin is granted, local authority at the village level, authority according to the tasks of the government, provincial government, or district/city regional government, and other authorities assigned by the Government, Provincial Government. Furthermore, the authority contained in the Village Law provides a foundation for villages to manage and regulate villagescale natural resources such as the forestry, plantation, mining and other natural resources sectors, including in the management of village scale tourism sectors both in coastal area and mountainous area. The regulation of natural resources spread in various laws and regulations is still very centralized, i.e. regarding the licensing is very centralistic, often overlapping the laws and regulations concerning the village as stipulated in the Village Law.

The Village Law provides significant opportunities for villages to manage natural resources through Village-Owned Enterprises (Badan Usaha Milik Desa) which in many villages in Indonesia have developed a lot of patterns, so that the villages really have independence in managing its natural resources, especially village-scale natural resources. In addition to managing village-scale natural resources by Village-owned Business Entity, the Village Law also gives authority to the village to make village-scale legislation (Perdes) which can be used as a legal basis in managing village-scale natural resources.

The Government through Law No. 2 of 2015 concerning Stipulation of Government Regulation As Substitute of Law No. 2 of 2014 concerning Amendments to Law No. 23 of 2014 concerning Regional Government Becoming a Law, granting village authority over natural resources is also regulated and confirmed in Article 371 paragraph (2) of Law No. 23 of 2014 concerning Regional Government, i.e. the Village has the authority in accordance with the provisions of the legislation concerning Villages.

According to Article 18 of the Village Law, village authority includes authority in field of village government implementation, village development implementation, rural community development, and rural community empowerment based on community initiatives, rights of origin, and village customs. Furthermore, according to Article 19 of the Village Law, the authority of the village covers: authority based on the rights of origin, local authority on a village scale, authorities assigned by the government, provincial government, or district/city regional government; and other authorities assigned by the government, provincial government, or district/city regional government.

Based on the mandated authority in the laws and regulations above, giving authority to the village to be able to carry out village development and rural areas by utilizing the potential of natural resources in the village in a sustainable manner, including the rights to natural resources in the forestry sector, mining (renewable new energy), agriculture, plantations, and tourism sector in the village scale. The arrangement aims to create a source of livelihood in the village through the utilization of village-scale natural resources to improve the welfare of the community, as stated in Article 78 paragraph (1).

From the regulation references above, it seems that the utilization of geothermal natural resources for the welfare of rural communities is not sufficient enough and even somewhat neglected, eventhough the regulation on village authority has clearly protected the village from the superstructure which has always exploited the village. The results of research on the obstacles to the use of geothermal energy for the welfare of rural communities, there is a hegemony by the district government by not issuing a Regent's Regulation on Village Authority, so that the Village is only an audience of process of the direct and indirect use of geothermal.

However, upstream regulation is good and needs to be directed towards downstream regulation and the commitment of law enforcement officers and employees of the central government and related regional governments so that the acceleration of geothermal utilization can be felt by rural communities around the location and community of the district and even the province that will enjoy electricity from indirect use of PLTP. Village independence which is 
the goal of the issuance of the Village Law, the government carries out a fiscal decentralization policy to the village in order to show the form of the large and progressive alignments of the central government that will prioritize the improvement of regional development in community service for the realization of community welfare, better known as Village Fund.

The funds can be used as village development capital through Village-owned Business Entity as stipulated in Article 87 to Article 90 of the Village Law with a pupose to encourage an increase in the economic scale in the productive business of rural community, including in the management of village-scale natural resources [7]. The village government has a very significant role in managing village-scale natural resources, given the location of these natural resources administratively in the village.

One of important instruments in realizing a prosperous village, especially in managing village-scale natural resources is through the formation of Village-owned Business Entity. This is one of significant step of Village authority. Village authority is the village's right to regulate, manage and be responsible for government affairs and the interests of the local community. The Village Law provides a legal basis that village community have the right to natural resources to manage natural resources for the welfare of village community. The potential natural resources in each village, in various regions of Indonesia are very different. Each village must be able to develop its potential. This potential must be managed professionally through the Village-owned Business Entity as a legal basis in the management of natural resources in the village.

\section{Conclusion}

There is no significant obstacles and obstructions in using geothermal energi for the welfare of village community in accordance with the Village Law, as well as technical regulations as stipulated in the Regulation of the Minister of Energy and Mineral Resources relating to geothermal management in the village. Meanwhile, for direct use, many doubt the ability of the village and the village community is able to do so, due to the authority is in Central Government. The existing regulatory support is adequate and there are no irregularities which mean that as long as the village includes geothermal utilization, it becomes a village-scale local authority. The village through the Village-owned Business Entity can carry out actions regarding the use of geothermal energy for the welfare of the village community.

\section{References}

1. Kementerian PPN/Bappenas, Metadata Indikator Tujuan Pembangunan Berkelanjutan (TPB) Sustainable Development Goals (SDGs) Indonesia: Pilar Pembangunan Ekonomi (2017)

2. S. Sigit, Sepenggal Sejarah Perkembangan Pertambangan Indonesia (2004)

3. D. Darmono, Mineral dan Energi Kekayaan Bangsa: Sejarah Pertambangan dan Energi Indonesia (2009)

4. J. Asshiddiqie, Perihal Undang-Undang (2006)

5. D. Pieters, Function of Comparative Law and Practical Methodology of Comparing (Duke University, 2010)

6. R. Michaels, The Functional Method of Comparative Law (Durham, 2006)

7. F. Sidik, Jurnal Kebijakan dan Administrasi Publik 19, 2 (2015) 